\title{
Studies on Oligomer Metal Complexes Derived from Bisamic Acid of Pyromellitic Dianhydride and 4-Bromoaniline
}

\author{
Yogesh S. Patel \\ Chemistry Department, Government Science College, Gandhinagar, Gujarat 382015, India \\ Correspondence should be addressed to Yogesh S. Patel; dryspatel@gmail.com
}

Received 25 April 2014; Accepted 19 September 2014; Published 30 October 2014

Academic Editor: Wen-Sheng Chen

Copyright ( 2014 Yogesh S. Patel. This is an open access article distributed under the Creative Commons Attribution License, which permits unrestricted use, distribution, and reproduction in any medium, provided the original work is properly cited.

\begin{abstract}
Novel oligomer metal complexes (2a-f) of the ligand 2,5-bis((4-bromophenyl)carbamoyl) terephthalic acid (1) were prepared using transition metal salts and characterized by various spectroscopic techniques. The geometry of oligomer metal complexes was carried out by electronic spectral analysis and magnetic measurement studies. Polymeric properties have also been carried out. Ligand was synthesized using pyromellitic dianhydride and 4-bromoaniline. It was duly characterized. All novel synthesized compounds 1 and 2a-f were evaluated for their antibacterial and antifungal activity. The results showed significantly higher antibacterial and antifungal activity of oligomer metal complexes compared to the ligand.
\end{abstract}

\section{Introduction}

The design and construction of polymeric metal complexes have received great attention [1-6]. The structures of metal complexes are depending upon the structure of the organic ligands, the coordinative geometry of metal ions, metalligand ratio, and other factors $[7,8]$. Among various organic ligands, multicarboxylate ligands are often used to synthesize polymer metal complexes; for example, 1,2,4,5-benzene-tetra carboxylate, $3,3^{\prime}, 4,4^{\prime}$-biphenyl tetra carboxylic acid $[9,10]$, $1,1^{\prime}$-biphenyl-2,3',3,4'-tetra carboxylic acid [11], and methylene diisophthalic acid [12] have been extensively used for the synthesis of various polymer metal complexes. On the other hand, the use of auxiliary $\mathrm{N}$-containing ligands is also an effective method for the framework formation of polymer metal complexes owing to the fact that they can satisfy and even mediate the coordination needs of the metal center and consequently generate more meaningful architectures $[13,14]$. The oligomer metal complex based on bisamic acid of pyromellitic dianhydride has not attracted any attention. Hence, initial work in this direction has been reported by us [15-18]. This prompted us to extend our work by using other auxiliary ligand such as 2,5-bis((4-bromophenyl) carbamoyl) terephthalic acid. With the aim of investigating the influence of ligand containing carboxylic and amide group (-O and $\mathrm{N}$ containing ligand) on the frameworks of metal complexes, we have carried out the study for the reaction of metal (II) salts with novel bisamic acid. Scheme 1 summarizes our synthetic approach to the synthesis of oligomer metal complexes using various metal (II) acetates, for example, $\mathrm{Mn}(\mathrm{II}), \mathrm{Fe}(\mathrm{II}), \mathrm{Co}(\mathrm{II}), \mathrm{Ni}(\mathrm{II}), \mathrm{Cu}(\mathrm{II})$, and $\mathrm{Zn}(\mathrm{II})$ metal ions. Ligand when incorporated with transition metal ions would produce a broad spectrum of antimicrobial property. The details of these procedures and the results obtained are discussed below.

\section{Experimental}

2.1. Materials and Measurements. All common reagents and solvents were used of analytical grade and were used without further purification. Alumina supported precoated silica gel 60 F254 thin layer chromatography (TLC) plates were purchased from the E. Merck (India) Limited, Mumbai, and were used to check purity of compounds and to study the progress of the reaction whereby TLC plates were illuminated under ultraviolet light $(254 \mathrm{~nm})$, evaluated in $\mathrm{I}_{2}$ vapors, and visualized by spraying with Dragendorff's reagent. Infrared spectra (FT-IR) were obtained from $\mathrm{KBr}$ pellets in the range of $4000-400 \mathrm{~cm}^{-1}$ with a Perkin Elmer spectrum GX spectrophotometer (FT-IR) instrument. ${ }^{1} \mathrm{H}$ NMR and ${ }^{13} \mathrm{C}$ NMR spectra were acquired at $400 \mathrm{MHz}$ on a Bruker NMR 


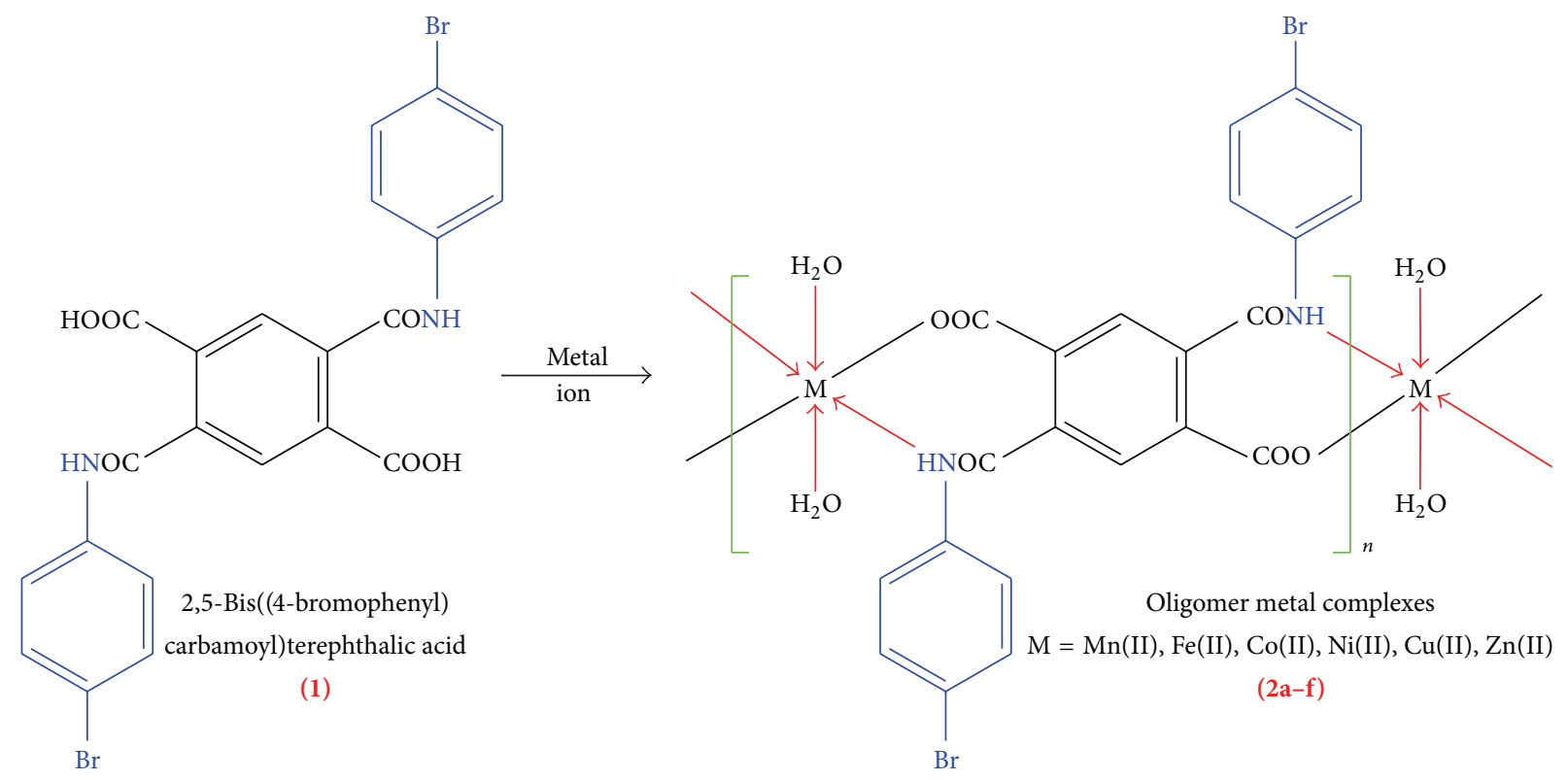

SCHEme 1: Synthetic route for the oligomer metal complexes.

spectrometer using DMSO- $d_{6}$ (residual peak at $\delta \sim 2.5$ or $\sim 39.5 \mathrm{ppm}, 300^{\circ} \mathrm{K}$ ) as a solvent as well as TMS an internal reference standard. Microanalytical $(\mathrm{C}, \mathrm{N}, \mathrm{H})$ data was obtained by using a Perkin Elmer $2400 \mathrm{CHN}$ elemental analyzer. The solid diffuse electronic spectra were recorded on a Beckman DK-2A spectrophotometer with a solid reflectance attachment. $\mathrm{MgO}$ was employed as a reference. Magnetic moments [19] were determined by the Gouy method with mercury tetrathiocyanatocobaltate (II), $\left[\mathrm{HgCo}(\mathrm{NCS})_{4}\right]$ as calibrant $\left(\mathrm{Xg}=1644 \times 10^{-6} \mathrm{cgs}\right.$ units at $\left.20^{\circ} \mathrm{C}\right)$, by Citizen Balance (at room temperature). Molar susceptibilities were corrected using Pascal's constant [20]. The thermogravimetric studies were carried out with a model Perkin Elmer thermogravimetric analyzer at a heating rate of $10^{\circ} \mathrm{C} \mathrm{min}^{-1}$ in the temperature range $50-700^{\circ} \mathrm{C}$. The metal content of the oligomer metal complexes was carried by decomposing a weighed amount of each oligomer metal complexes with $\mathrm{HClO}_{4}, \mathrm{H}_{2} \mathrm{SO}_{4}$, and $\mathrm{HNO}_{3}(1: 1.5: 2.5)$ mixture followed by standard EDTA titration method [21]. Number average molecular weight $(\overline{\mathrm{Mn}})$ of oligomer metal complexes was determined by nonaqueous conductometric titration. It was carried out in pyridine solution against standard sodium methoxide in pyridine solution as titrant. The number average molecular weight of each sample was calculated according to method reported in the literature [22]. The melting point was checked by the standard open capillary method. In order to facilitate the correct structural assessment, that is, the coordination site, we have tried a lot to generate a crystal for single crystal X-ray analysis but we did not succeed. Hasanzadeh et al. [23] have reported this type of acid amide metal complex. So from the obtained data and reference article, interpretations become straightforward.

2.2. Synthesis of Ligand 2,5-Bis((4-bromophenyl) carbamoyl) Terephthalic Acid (1). Adding a solution dropwise of 4bromoaniline $(24.40 \mathrm{~g}, 0.2 \mathrm{~mol})$ to a stirred solution of pyromellitic dianhydride $(21.813 \mathrm{~g}, 0.1 \mathrm{~mol})$ and keeping the temperature of the medium close to $40-50^{\circ} \mathrm{C}$ for an hour (Scheme 1), thus obtained ensuing solution was poured into ice water in which the reaction product precipitated. The final white precipitates were filtered, washed, and purified by column chromatography. Physicochemical parameters and FT-IR spectral data were mentioned in Tables 1 and 2, respectively: ${ }^{1} \mathrm{H}$ NMR (DMSO- $d_{6}, \delta \mathrm{ppm}$ ): 10.87 (s, $2 \mathrm{H},-\mathrm{COOH}$ ), 9.09 (s, 2H, -NH-), 8.48 (s, 2H, Ar-H), 7.66 (d, 4H, Ar-H), and 7.49 (d, $4 \mathrm{H}, \mathrm{Ar}-\mathrm{H}) ;{ }^{13} \mathrm{C}$ NMR (DMSO- $\left.d_{6}, \delta \mathrm{ppm}\right): 121.3$, $122.7,126.8,130.9,134.3,135.2,136.8,167.9$, and 171.2.

\subsection{Synthesis of Oligomer Metal Complexes (2a-f). All} oligomer metal complexes were synthesized by using equimolar amount of ligand and various metal (II) salts. To a warm clear solution of ligand $(5.621 \mathrm{~g}, 0.01 \mathrm{~mol})$ in $20 \mathrm{~mL}$ of dimethylsulphoxide add $0.1 \mathrm{M}$ sodium hydroxide solution and $\mathrm{pH}$ about 7-8 was maintained. A pasty mass was observed. It was diluted with water to make a solution clear. To the above solution, metal (II) acetate solution $(0.01 \mathrm{~mol})$ was added with constant stirring and the $\mathrm{pH}$ of the reaction mixture was adjusted to 6-7 for $\mathbf{2 a}, \mathbf{2 b}, \mathbf{2 c}, \mathbf{2 d}$, and $\mathbf{2 f}$ and $4-5$ for 2e. Thus oligomer metal complexes were separated out in the form of a suspension. It was digested on a water bath for $1 \mathrm{~h}$, filtered, washed, and dried in air at room temperature. These oligomer metal complexes designated as $\mathbf{2 a - f}$ are insoluble in common organic solvents like methanol, ethanol, chloroform, acetone, and benzene.

\subsection{Biological Activity}

2.4.1. Antibacterial Activity (In Vitro). Compounds (1 and $\mathbf{2 a}-\mathbf{f}$ ) were screened for in vitro antibacterial activity against Gram-positive bacterial strains (Bacillus subtilis (BS) and Staphylococcus aureus (SA)) and Gram-negative bacterial 
TABle 1: Physicochemical parameters of the ligand and its oligomer metal complexes.

\begin{tabular}{|c|c|c|c|c|c|c|c|c|c|c|c|c|}
\hline \multirow{2}{*}{\multicolumn{2}{|c|}{$\begin{array}{c}\text { Empirical formula of } \\
\text { compound }\end{array}$}} & \multirow{3}{*}{$\begin{array}{c}\begin{array}{l}\text { Empirical } \\
\text { weight }(\mathrm{gm})\end{array} \\
562.16\end{array}$} & \multirow{3}{*}{$\begin{array}{l}\text { Color } \\
\text { ight yellow }\end{array}$} & \multirow{3}{*}{$\begin{array}{c}\text { Yield \% } \\
65\end{array}$} & \multirow{3}{*}{\begin{tabular}{|l}
$\begin{array}{l}\text { M.P. }{ }^{\mathrm{a}} \\
\left({ }^{\circ} \mathrm{C}\right)\end{array}$ \\
$160^{\mathrm{b}}$
\end{tabular}} & \multicolumn{4}{|c|}{ Elemental analysis calc. (found \%) } & \multirow{3}{*}{$\begin{array}{c}\mu_{\text {eff }} \text { B.M. } \\
-\end{array}$} & \multirow{3}{*}{$\begin{array}{l}\bar{M}_{n} \\
-\end{array}$} & \multirow{3}{*}{$\begin{array}{l}\text { DP } \\
-\end{array}$} \\
\hline & & & & & & \multirow{2}{*}{$\begin{array}{c}\mathrm{C} \\
47.00 \\
(46.89) \\
\end{array}$} & \multirow{2}{*}{$\begin{array}{c}\mathrm{H} \\
2.51 \\
(2.46) \\
\end{array}$} & \multirow{2}{*}{$\begin{array}{c}\mathrm{N} \\
4.98 \\
(4.92) \\
\end{array}$} & \multirow{2}{*}{$\begin{array}{l}M \\
-\end{array}$} & & & \\
\hline 1 & $\begin{array}{c}\mathrm{L} \\
\mathrm{C}_{22} \mathrm{H}_{14} \mathrm{Br}_{2} \mathrm{~N}_{2} \mathrm{O}_{6} \\
\end{array}$ & & & & & & & & & & & \\
\hline $2 \mathbf{a}$ & $\begin{array}{l}\left.\mathrm{Mn}-\mathrm{L}-\left(\mathrm{H}_{2} \mathrm{O}\right)_{2}\right]_{n} \\
\mathrm{C}_{22} \mathrm{H}_{16} \mathrm{Br}_{2} \mathrm{~N}_{2} \mathrm{O}_{8} \mathrm{Mn}\end{array}$ & 651.12 & White & 45 & $>250$ & $\begin{array}{c}40.58 \\
(40.50)\end{array}$ & $\begin{array}{c}2.48 \\
(2.43)\end{array}$ & $\begin{array}{c}4.30 \\
(4.25)\end{array}$ & $\begin{array}{c}8.44 \\
(8.40)\end{array}$ & 5.54 & 3250 & 5 \\
\hline $2 \mathbf{b}$ & $\begin{array}{l}{\left[\mathrm{Fe}-\mathrm{L}-\left(\mathrm{H}_{2} \mathrm{O}\right)_{2}\right]_{n}} \\
\mathrm{C}_{22} \mathrm{H}_{16} \mathrm{Br}_{2} \mathrm{~N}_{2} \mathrm{O}_{8} \mathrm{Fe}\end{array}$ & 652.02 & Light brown & 58 & $>250$ & $\begin{array}{c}40.53 \\
(40.45)\end{array}$ & $\begin{array}{c}2.47 \\
(2.42)\end{array}$ & $\begin{array}{c}4.30 \\
(4.23)\end{array}$ & $\begin{array}{c}8.56 \\
(8.50)\end{array}$ & 4.98 & 3901 & 6 \\
\hline 2c & $\begin{array}{l}{\left[\mathrm{Co}-\mathrm{L}-\left(\mathrm{H}_{2} \mathrm{O}\right)_{2}\right]_{n}} \\
\mathrm{C}_{22} \mathrm{H}_{16} \mathrm{Br}_{2} \mathrm{~N}_{2} \mathrm{O}_{8} \mathrm{Co}\end{array}$ & 655.11 & Light pink & 55 & $>250$ & $\begin{array}{c}40.33 \\
(40.25) \\
\end{array}$ & $\begin{array}{c}2.46 \\
(2.40) \\
\end{array}$ & $\begin{array}{c}4.28 \\
(4.21) \\
\end{array}$ & $\begin{array}{c}9.00 \\
(8.92) \\
\end{array}$ & 4.25 & 3257 & 5 \\
\hline $2 d$ & $\begin{array}{l}{\left[\mathrm{Ni}-\mathrm{L}-\left(\mathrm{H}_{2} \mathrm{O}\right)_{2}\right]_{n}} \\
\mathrm{C}_{22} \mathrm{H}_{16} \mathrm{Br}_{2} \mathrm{~N}_{2} \mathrm{O}_{8} \mathrm{Ni}\end{array}$ & 654.87 & Light green & 63 & $>250$ & $\begin{array}{c}40.35 \\
(40.30) \\
\end{array}$ & $\begin{array}{c}2.46 \\
(2.41) \\
\end{array}$ & $\begin{array}{c}4.28 \\
(4.26) \\
\end{array}$ & $\begin{array}{c}8.96 \\
(8.92) \\
\end{array}$ & 2.87 & 3250 & 5 \\
\hline $2 e$ & $\begin{array}{l}{\left[\mathrm{Cu}-\mathrm{L}-\left(\mathrm{H}_{2} \mathrm{O}\right)_{2}\right]_{n}} \\
\mathrm{C}_{22} \mathrm{H}_{16} \mathrm{Br}_{2} \mathrm{~N}_{2} \mathrm{O}_{8} \mathrm{Cu}\end{array}$ & 659.73 & Green & 70 & $>250$ & $\begin{array}{c}40.05 \\
(40.00) \\
\end{array}$ & $\begin{array}{c}2.44 \\
(2.38) \\
\end{array}$ & $\begin{array}{c}4.25 \\
(4.21) \\
\end{array}$ & $\begin{array}{c}9.63 \\
(9.58) \\
\end{array}$ & 1.99 & 3941 & 6 \\
\hline $2 f$ & $\begin{array}{l}{\left[\mathrm{Zn}-\mathrm{L}-\left(\mathrm{H}_{2} \mathrm{O}\right)_{2}\right]_{n}} \\
\mathrm{C}_{22} \mathrm{H}_{16} \mathrm{Br}_{2} \mathrm{~N}_{2} \mathrm{O}_{8} \mathrm{Zn}\end{array}$ & 661.56 & White & 45 & $>250$ & $\begin{array}{c}39.94 \\
(39.88)\end{array}$ & $\begin{array}{c}2.44 \\
(2.39)\end{array}$ & $\begin{array}{c}4.23 \\
(4.17)\end{array}$ & $\begin{array}{c}9.88 \\
(9.82)\end{array}$ & $\mathrm{D}$ & 3312 & 5 \\
\hline
\end{tabular}

${ }^{\mathrm{a}}$ Melting points were checked by standard open capillary method and were found uncorrected; ${ }^{\mathrm{b}}$ uncorrected.

$\mu_{\text {eff }}$ B.M.: magnetic moment, $\bar{M}_{n}$ : number of average molecular weights, DP: degree of polymerization, and D: diamagnetic.

TABLE 2: FT-IR frequencies and electronic spectral data of the ligand and its oligomer metal complexes.

\begin{tabular}{|c|c|c|c|c|c|c|c|c|c|c|c|c|}
\hline \multirow{2}{*}{\multicolumn{2}{|c|}{ Compound }} & \multirow{3}{*}{$\frac{-\mathrm{COOH}}{3555}$} & \multirow{3}{*}{$\frac{-\mathrm{CONH}}{3237}$} & \multirow{3}{*}{$\begin{array}{c}-\mathrm{OH} \\
-\end{array}$} & \multirow{3}{*}{$\begin{array}{r}-\mathrm{C}=\mathrm{O} \\
1712\end{array}$} & \multirow{3}{*}{$\frac{-\mathrm{CONH}}{1688}$} & \multirow{3}{*}{$\begin{array}{r}\mathrm{COO}^{-} \\
1465\end{array}$} & \multirow{3}{*}{$\begin{array}{l}\mathrm{C}-\mathrm{O} \\
1047 \\
\end{array}$} & \multirow{3}{*}{$\begin{array}{c}\mathrm{M}-\mathrm{O} \\
-\end{array}$} & \multirow{3}{*}{$\begin{array}{c}\mathrm{M}-\mathrm{N} \\
-\end{array}$} & \multicolumn{2}{|c|}{ Electronic spectral data } \\
\hline & & & & & & & & & & & $\mathrm{cm}^{-1}$ & Transitions \\
\hline 1 & $\mathrm{~L}$ & & & & & & & & & & - & - \\
\hline $2 a$ & {$\left[\mathrm{Mn}-\mathrm{L}-\left(\mathrm{H}_{2} \mathrm{O}\right)_{2}\right]_{n}$} & - & 3212 & 2982 & 1692 & 1665 & 1453 & 1029 & 623 & 528 & $\begin{array}{l}16,486 \\
17,769 \\
23,140\end{array}$ & $\begin{array}{l}6_{\mathrm{Alg}} \rightarrow 4_{\mathrm{Tlg}}(4 \mathrm{G}) \\
6_{\mathrm{Alg}} \rightarrow 4_{\mathrm{T} 2 \mathrm{~g}}(4 \mathrm{G}) \\
6_{\mathrm{Alg}} \rightarrow 4_{\mathrm{Alg}}, 4_{\mathrm{Eg}}\end{array}$ \\
\hline $2 b$ & {$\left[\mathrm{Fe}-\mathrm{L}-\left(\mathrm{H}_{2} \mathrm{O}\right)_{2}\right]_{n}$} & - & 3220 & 2979 & 1694 & 1673 & 1455 & 1026 & 628 & 531 & $\begin{array}{c}19011 \\
36062 \\
\end{array}$ & $\begin{array}{l}5_{\mathrm{T} 2 \mathrm{~g}}(\mathrm{~F}) \rightarrow 3_{\mathrm{Eg}} \\
5_{\mathrm{T} 2 \mathrm{~g}}(\mathrm{~F}) \rightarrow 3_{\mathrm{Tlg}}\end{array}$ \\
\hline $2 c$ & {$\left[\mathrm{Co}-\mathrm{L}-\left(\mathrm{H}_{2} \mathrm{O}\right)_{2}\right]_{n}$} & - & 3211 & 2983 & 1690 & 1672 & 1447 & 1028 & 630 & 529 & $\begin{array}{c}9,845 \\
15,553 \\
22,948 \\
\end{array}$ & $\begin{array}{l}4_{\mathrm{Tlg}}(\mathrm{F}) \rightarrow 4_{\mathrm{T} 2 \mathrm{~g}}(\mathrm{~F}) \\
4_{\mathrm{Tlg}}(\mathrm{F}) \rightarrow 4_{\mathrm{A} 2 \mathrm{~g}}(\mathrm{~F}) \\
4_{\mathrm{Tlg}}(\mathrm{F}) \rightarrow 4_{\mathrm{Tlg}}(\mathrm{P})\end{array}$ \\
\hline $2 d$ & {$\left[\mathrm{Ni}-\mathrm{L}-\left(\mathrm{H}_{2} \mathrm{O}\right)_{2}\right]_{n}$} & - & 3214 & 2977 & 1695 & 1669 & 1449 & 1025 & 634 & 526 & $\begin{array}{c}9,851 \\
15,570 \\
22,934 \\
\end{array}$ & $\begin{array}{l}3_{\mathrm{A} 2 \mathrm{~g}} \rightarrow 3_{\mathrm{T} 2 \mathrm{~g}} \\
3_{\mathrm{A} 2 \mathrm{~g}} \rightarrow 3_{\mathrm{Tlg}}(\mathrm{F}) \\
3_{\mathrm{A} 2 \mathrm{~g}} \rightarrow 3_{\mathrm{Tlg}}(\mathrm{P})\end{array}$ \\
\hline $2 \mathrm{e}$ & {$\left[\mathrm{Cu}-\mathrm{L}-\left(\mathrm{H}_{2} \mathrm{O}\right)_{2}\right]_{n}$} & - & 3225 & 2969 & 1689 & 1671 & 1450 & 1027 & 629 & 532 & $\begin{array}{l}15,949 \\
22,746\end{array}$ & $\begin{array}{l}2_{\mathrm{T} 2 \mathrm{~g}} \rightarrow 2_{\mathrm{Eg}} \\
\text { charge transfer }\end{array}$ \\
\hline $2 f$ & {$\left[\mathrm{Zn}-\mathrm{L}-\left(\mathrm{H}_{2} \mathrm{O}\right)_{2}\right]_{n}$} & - & 3213 & 2973 & 1687 & 1668 & 1446 & 1026 & 632 & 527 & - & - \\
\hline
\end{tabular}

strains (Salmonella typhimurium (ST) and Escherichia coli (EC)) utilizing the agar diffusion assay [24, 25]. The wells were dug in the media with the help of a sterile metallic borer. Recommended concentration $(100 \mu \mathrm{L})$ of the test sample $(1 \mathrm{mg} / \mathrm{mL}$ in DMSO) was introduced in the respective wells. Other wells supplemented with DMSO and reference antibacterial drug, ciprofloxacin, were served as negative and positive controls, respectively. The plates were incubated immediately at $37^{\circ} \mathrm{C}$ for 24 hours. Activity was determined by measuring the diameter of zones showing complete inhibition ( $\mathrm{mm})$. Growth inhibition was compared with the standard drug. In order to clarify any participating role of DMSO in the biological screening, separate studies were carried out with the solutions alone of DMSO and they showed no activity against any bacterial strains.
2.4.2. Antifungal Activity (In Vitro). Compounds (1 and 2a-f) were also examined for antifungal activity against different fungal strains, that is, Penicillium expansum (PE), Botryodiplodia theobromae (BT), Nigrospora sp. (NS), and Trichothecium sp. (TS). The antifungal drug, ketoconazole, was used as a positive control. Antifungal screening for compounds ( $\mathbf{1}$ and $\mathbf{2} \mathbf{a}-\mathbf{f}$ ) and positive control was performed at a recommended concentration. The fungal strains were grown and maintained on potato dextrose agar plates. The cultures of the fungi were purified by single spore isolation technique. Each compound (1 and $\mathbf{2 a - f}$ ) in DMSO solution was prepared for testing against spore germination of each fungus. The fungal culture plates were inoculated and incubated at $25 \pm 2^{\circ} \mathrm{C}$ for $48 \mathrm{~h}$. The plates were then observed and the diameters of the zone of inhibition (in $\mathrm{mm}$ ) were 
measured. The percentage inhibition for fungi was calculated after five days using the formula given below:

$$
\text { Percentage of inhibition }=\frac{100(X-Y)}{X},
$$

where $X$ is area of colony in control plate and $Y$ is area of colony in test plate.

\section{Results and Discussion}

3.1. Synthesis of Ligand 2,5-Bis((4-bromophenyl) carbamoyl) Terephthalic Acid (1). To the best of our knowledge, ligand (1) has not been reported previously. The characterization of the reaction product provided the first unambiguous proof of the successful synthesis of 2,5-bis((4bromophenyl)carbamoyl)terephthalic acid. The FT-IR spectrum of ligand showed the most relevant peaks of the aromatic ring and 1,2,4,5-tetra substituted benzene ring, other than typical absorptions arising from the band at $3555 \mathrm{~cm}^{-1}$ and $1712 \mathrm{~cm}^{-1}$ for carboxylic acid and $3237 \mathrm{~cm}^{-1}$ and $1688 \mathrm{~cm}^{-1}$ for $\mathrm{O}=\mathrm{C}-\mathrm{NH}$ group [26]. In the ${ }^{1} \mathrm{H} \mathrm{NMR}$ spectroscopy, the signals in the range of $8.48,7.66$, and $7.49 \mathrm{ppm}$ were ascribed to the protons of the aromatic rings. The singlet at $10.87 \mathrm{ppm}$ was ascribed to the protons of carboxylic -OH group and a singlet at $9.09 \mathrm{ppm}$ was attributed to the $-\mathrm{NH}$ proton of amide group, which was further confirmed by ${ }^{13} \mathrm{C} \mathrm{NMR}$ value, that is, 167.9 and 171.2 attributed to carboxylic carbon and amide carbon, respectively. The expected structure was thus clearly verified by the spectroscopic analysis which indicated moreover the absence of any detectable impurity, particularly of the two reagents used to prepare ligand.

\subsection{Synthesis of Oligomer Metal Complexes}

3.2.1. Physical Properties. Elemental analysis of all polymer metal complexes was in good agreement with proposed structures. All polymer metal complexes exhibited 1:1 metal to ligand stoichiometry. The structures of oligomer metal complexes were consistent with the FT-IR, electronic spectra, and TGA. The geometry of the central metal ion was confirmed by electronic spectra and magnetic susceptibility measurements. The degrees of polymerization (DP) for all oligomer metal complexes are in the range of 5 to 6 (Table 1 ). All the data provides good evidence that the chelates are polymeric in nature. The suggested structure of the polymer metal complexes is shown in Scheme 1.

3.2.2. Infrared Spectra. IR spectral bands of the ligand and its oligomer metal complexes suggest the formation of desired oligomer metal complexes and support their structure. Spectral features provide valuable information regarding the nature of functional group attached to the metal atom (Figure 1). In order to study the bonding mode of ligand to the oligomer metal complexes, the IR spectrum of free ligand was compared with the spectra of oligomer metal complexes (Table 2). Considerable differences to be expected were observed. The band at about $3555 \mathrm{~cm}^{-1}$ for carboxylic

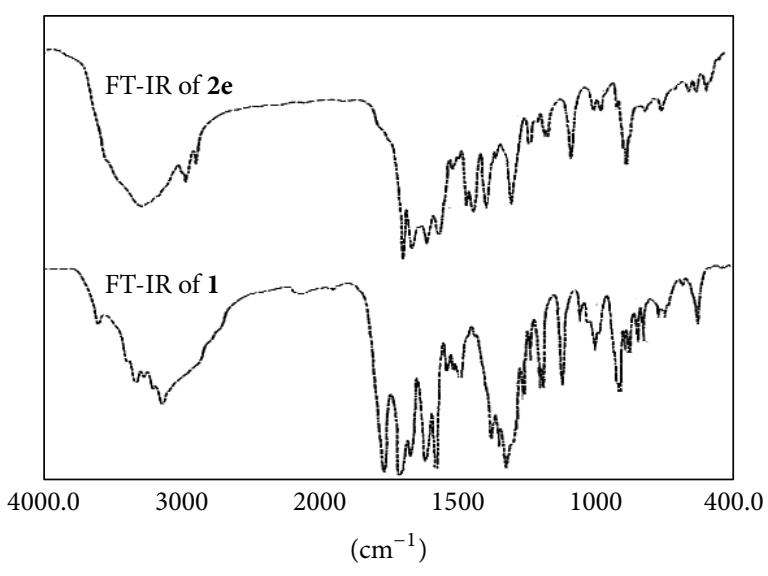

FIgURE 1: FT-IR of ligand and $\mathrm{Cu}$-metal complex.

acid in ligand had virtually disappeared from the spectra of oligomer metal complexes. Oligomer metal complexes exhibit more broadened band in the region near $2980 \mathrm{~cm}^{-1}$ indicating the presence of coordinated water molecules [27]. The coordinated water in all the oligomer metal complexes presents different peaks at $980 \mathrm{~cm}^{-1}$ (rocking) and $770 \mathrm{~cm}^{-1}$ (wagging), whereas none of these vibrations appear in the spectra of uncoordinated ligands. A band at $\sim 1640 \mathrm{~cm}^{-1}$ in free ligand is due to $\nu \mathrm{C}-\mathrm{N}$ vibration. The shifting of this group to lower frequency $\left(\sim 1610 \mathrm{~cm}^{-1}\right)$ in the oligomer metal complexes when compared to free ligand suggested the coordination of metal ion through nitrogen atom of amide group [28]; it is expected that coordination of nitrogen to the metal atom would reduce the electron density in the amide link and thus lower the absorption [29]. A band at $1712 \mathrm{~cm}^{-1}$ is assigned to $\nu \mathrm{C}=\mathrm{O}$ stretching frequency in the spectrum of free ligand which is also shifted to lower frequency ranging from 1687 to $1694 \mathrm{~cm}^{-1}$ in all the oligomer metal complexes. This indicates the involvement of oxygen atom of hydroxyl group of $-\mathrm{COOH}$ group in bonding with metal ions [30]. New bands, which were not present in the spectrum of ligand, appeared in the spectra of oligomer metal complexes; for example, presence of sharp band in the region of 525$535 \mathrm{~cm}^{-1}$ can be assigned to $\nu \mathrm{M}-\mathrm{N}$ [30], which indicated the involvement of nitrogen in coordination. The medium intensity bands for $\nu \mathrm{M}-\mathrm{O}$ [31] have been observed at 625$635 \mathrm{~cm}^{-1}$ due to $\mathrm{M}-\mathrm{O}$ coordination. The appearance of $\nu \mathrm{M}-$ $\mathrm{N}$ and $\nu \mathrm{M}-\mathrm{O}$ vibrations supports the involvement of $\mathrm{N}$ and $\mathrm{O}$ atoms in complexation with metal ions under investigation. These overall data suggest that the amide- $\mathrm{N}$ and carboxylate$\mathrm{O}$ groups are involved in coordination with the metal (II) ion in oligomer metal complexes. These features confirmed the proposed structure of oligomer metal complexes as shown in Scheme 1.

3.2.3. Magnetic Moments and Electronic Spectral Data. The information regarding geometry of the oligomeric metal complexes were obtained from their electronic spectral data and magnetic moment values (Table 2). The diffuse electronic spectrum of the $\left[\mathrm{Cu}(\mathrm{L})\left(\mathrm{H}_{2} \mathrm{O}\right)_{2}\right]_{n}$ shows two broad bands 
around $15,949 \mathrm{~cm}^{-1}$ and $22,746 \mathrm{~cm}^{-1}$ due to the $2_{\mathrm{T} 2 \mathrm{~g}} \rightarrow 2_{\mathrm{Eg}}$ transition while the second may be due to charge transfer, respectively. This suggests a distorted octahedral structure for the $\left[\mathrm{Cu}(\mathrm{L})\left(\mathrm{H}_{2} \mathrm{O}\right)_{2}\right]_{n}$ polymer which was further confirmed by its $\mu_{\text {eff }}$ value 1.99 B.M. The $\left[\mathrm{Ni}(\mathrm{L})\left(\mathrm{H}_{2} \mathrm{O}\right)_{2}\right]_{n}$ coordination polymer shows two absorption bands at $15,570 \mathrm{~cm}^{-1}, 22,934 \mathrm{~cm}^{-1}$, and $9,851 \mathrm{~cm}^{-1}$ due to $3_{\mathrm{A} 2 \mathrm{~g}} \rightarrow 3_{\mathrm{T} 1 \mathrm{~g}}(\mathrm{~F})$ and $3_{\mathrm{A} 2 \mathrm{~g}} \rightarrow$ $3_{\mathrm{T} 1 \mathrm{~g}}(\mathrm{P})$ and $3_{\mathrm{A} 2 \mathrm{~g}} \rightarrow 3_{\mathrm{T} 2 \mathrm{~g}}$, respectively. The $\left[\mathrm{Co}(\mathrm{L})\left(\mathrm{H}_{2} \mathrm{O}\right)_{2}\right]_{n}$ polymer shows that two absorption bands, at $22,948 \mathrm{~cm}^{-1}$, $15,553 \mathrm{~cm}^{-1}$, and $9,845 \mathrm{~cm}^{-1}$ corresponding to $4_{\mathrm{T} 1 \mathrm{~g}}(\mathrm{~F}) \rightarrow$ $4_{\mathrm{T} 1 \mathrm{~g}}(\mathrm{P}), 4_{\mathrm{T} 1 \mathrm{~g}}(\mathrm{~F}) \rightarrow 4_{\mathrm{A} 2 \mathrm{~g}}(\mathrm{~F})$, and $4_{\mathrm{T} 1 \mathrm{~g}}(\mathrm{~F}) \rightarrow 4_{\mathrm{T} 2 \mathrm{~g}}(\mathrm{~F})$ transitions, respectively, indicated an octahedral configuration for the $\left[\mathrm{Ni}(\mathrm{L})\left(\mathrm{H}_{2} \mathrm{O}\right)_{2}\right]_{n}$ and $\left[\mathrm{Co}(\mathrm{L})\left(\mathrm{H}_{2} \mathrm{O}\right)_{2}\right]_{n}$ polymers [32]. This configuration was further confirmed by its $\mu_{\text {eff }}$ values 2.87 B.M. and 4.25 B.M. The spectrum of $\left[\mathrm{Fe}(\mathrm{L})\left(\mathrm{H}_{2} \mathrm{O}\right)_{2}\right]_{n}$ shows bands at $36,062 \mathrm{~cm}^{-1}$ and $19,011 \mathrm{~cm}^{-1}$ assigned to the transitions $5_{\mathrm{T} 2 \mathrm{~g}}(\mathrm{~F}) \rightarrow 3_{\mathrm{T} 1 \mathrm{~g}}$ and $5_{\mathrm{T} 2 \mathrm{~g}}(\mathrm{~F}) \rightarrow 3_{\mathrm{Eg}}$ and its $\mu_{\mathrm{eff}}$ 4.98 B.M. suggesting octahedral configuration. The spectrum of $\left[\mathrm{Mn}(\mathrm{L})\left(\mathrm{H}_{2} \mathrm{O}\right)_{2}\right]_{n}$ shows weak bands at 16,468, 17,769, and $23,140 \mathrm{~cm}^{-1}$ assigned to the transitions $6_{\mathrm{Alg}} \rightarrow 4_{\mathrm{Tlg}}(4 \mathrm{G})$, $6_{\mathrm{Alg}} \rightarrow 4_{\mathrm{T} 2 \mathrm{~g}}(4 \mathrm{G})$, and $6_{\mathrm{Alg}} \rightarrow 4_{\mathrm{Alg}}, 4_{\mathrm{Eg}}$, respectively, suggesting an octahedral structure for the $\left[\mathrm{Mn}(\mathrm{L})\left(\mathrm{H}_{2} \mathrm{O}\right)_{2}\right]_{n}$ polymer [33]. This configuration was further confirmed by its $\mu_{\text {eff }}$ value 5.54 B.M. As the spectrum of the $\left[\mathrm{Zn}(\mathrm{L})\left(\mathrm{H}_{2} \mathrm{O}\right)_{2}\right]_{n}$ polymer is not well interpreted, its $\mu_{\text {eff }}$ value shows that it is diamagnetic as expected. Magnetic moments $\mu_{\text {eff }}$ of all oligomer metal complexes revealed that all oligomers except $\mathrm{Zn}$ (II) metal ion polymer are paramagnetic while $\mathrm{Zn}$ (II) metal ion oligomer is diamagnetic.

3.2.4. Thermal Analysis. The thermal behavior was investigated by Perkin Elmer TGA analyzer at a heating rate of $10^{\circ} \mathrm{C}$ $\min ^{-1}$ in the temperature range $50-700^{\circ} \mathrm{C}$ under nitrogen which provides much information about the coordination compounds. In all the oligomer metal complexes, decomposition occurred in two steps (Figure 2). First step occurred between $100^{\circ} \mathrm{C}$ and $200^{\circ} \mathrm{C}$ which might be attributed to mass loss corresponding to water molecules. The value of weight loss during this step was consistent with theoretical value of two water molecules indicating that two water molecules were coordinated to the metal ion. Second step occurred between $200^{\circ} \mathrm{C}$ and $700^{\circ} \mathrm{C}$ which exhibits a mass loss corresponding to decomposition of ligand part in polymer. The weight loss of polymer metal complexes was noticeable between 300 and $600^{\circ} \mathrm{C}$. The rate of degradation became maximum at a temperature between $400^{\circ} \mathrm{C}$ and $600^{\circ} \mathrm{C}$. This may be due to acceleration by metal oxide which forms in situ. Each polymer loses about $80 \%$ of its weight when heated up to $700^{\circ} \mathrm{C}$. On the basis of the relative decomposition (\% weight loss) and the nature of thermogram, the oligomer metal complexes may be arranged in the order of their increasing stability as $\mathrm{Cu}<\mathrm{Fe}<\mathrm{Ni}<\mathrm{Co}<\mathrm{Zn}<\mathrm{Mn}$.

\subsection{Biological Activity}

3.3.1. Antibacterial Activity. Based on the data from the antibacterial studies against both Gram-positive and Gramnegative bacterial strains, the following observations can be

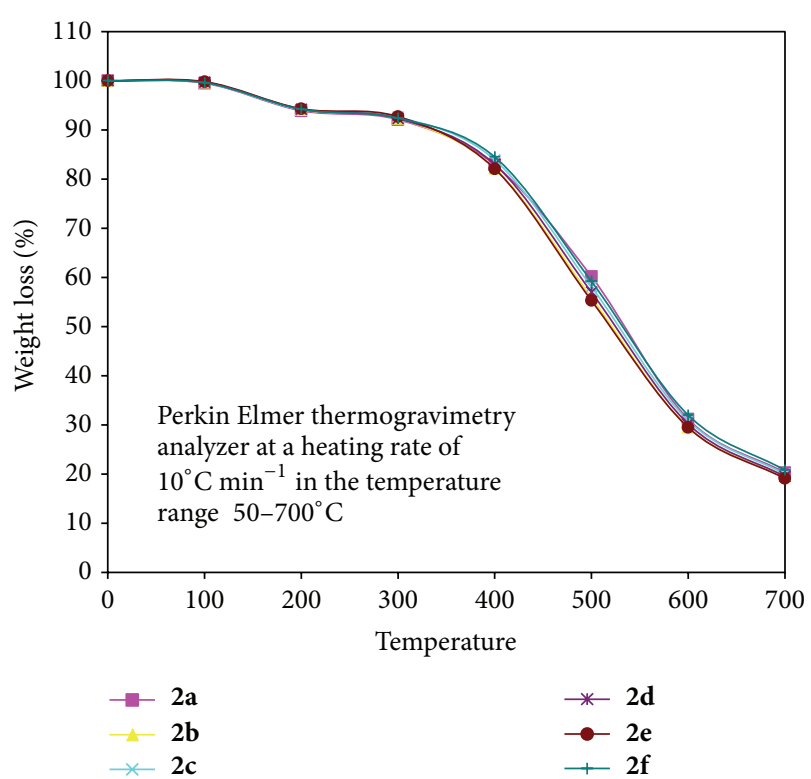

FIgURE 2: Thermogram of oligomer metal complexes.

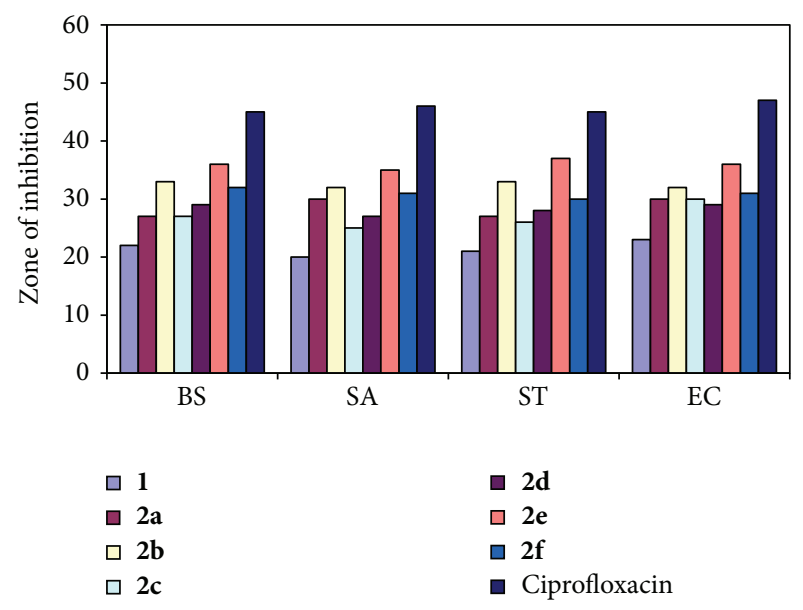

FIgure 3: Antibacterial activity of ligand and its oligomer metal complexes.

made. All compounds ( $\mathbf{1}$ and $\mathbf{2 a - f}$ ) exhibited antibacterial activity against both Gram-positive and Gram-negative bacterial strains with zones of inhibition (ZOI) ranging from $20 \mathrm{~mm}$ to $37 \mathrm{~mm}$ (Figure 3 ).

Schiff base 2,5-bis((4-bromophenyl) carbamoyl)terephthalic acid was found less active than its metal complexes. Among the analogs $\mathbf{2 a - f}$, compound $2 \mathrm{e}\left(\mathrm{ZOI}_{(\mathrm{BS})}=36 \mathrm{~mm}\right.$, $\mathrm{ZOI}_{(\mathrm{SA})}=35 \mathrm{~mm}, \mathrm{ZOI}_{(\mathrm{ST})}=37 \mathrm{~mm}$, and $\left.\mathrm{ZOI}_{(\mathrm{EC})}=36 \mathrm{~mm}\right)$ was identified as a potent antibacterial agent against all Grampositive and Gram-negative bacterial strains. Compound 2b $\left(\mathrm{ZOI}_{(\mathrm{BS})}=33 \mathrm{~mm}, \mathrm{ZOI}_{(\mathrm{SA})}=32 \mathrm{~mm}, \mathrm{ZOI}_{(\mathrm{ST})}=33 \mathrm{~mm}\right.$, and $\mathrm{ZOI}_{(\mathrm{EC})}=32 \mathrm{~mm}$ ) also had good antibacterial activity against bacterial strains. Compounds 2 a, 2c, 2d, and $\mathbf{2 f}$ exhibited moderate antibacterial activity. Compounds 1 and 2a-f exhibited less antibacterial activity as compared to 


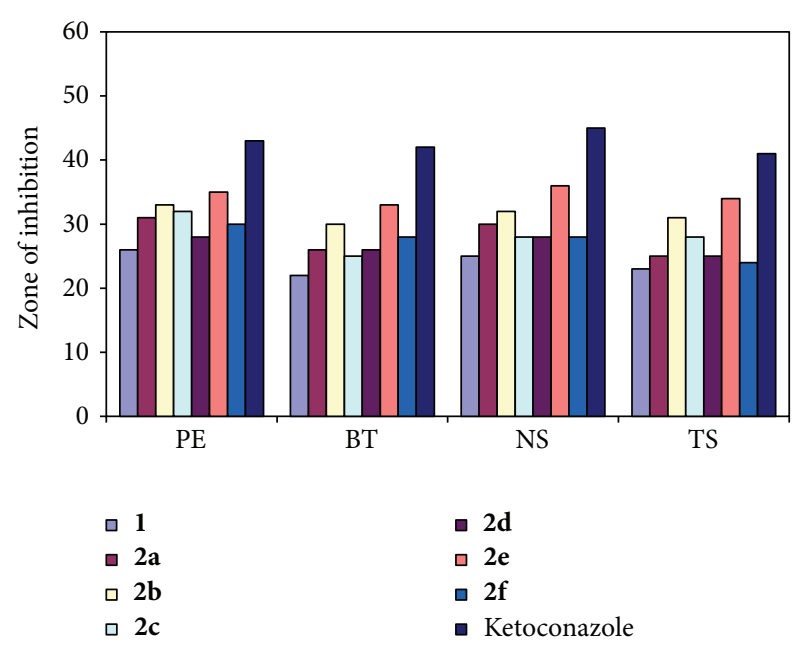

Figure 4: Antifungal activity of ligand and its oligomer metal complexes.

standard antibiotic drug, ciprofloxacin $\left(\mathrm{ZOI}_{(\mathrm{BS})}=45 \mathrm{~mm}\right.$, $\mathrm{ZOI}_{(\mathrm{SA})}=46 \mathrm{~mm}, \mathrm{ZOI}_{(\mathrm{ST})}=45 \mathrm{~mm}$, and $\left.\mathrm{ZOI}_{(\mathrm{EC})}=47 \mathrm{~mm}\right)$.

Comparative study of the growth inhibition zone values of Schiff base and its oligomer metal complexes indicated that the oligomer metal complexes exhibited higher antibacterial activity than free Schiff base (Figure 3). Such increased activity of the oligomer metal complexes can be explained on the basis of Overtone's concept and Tweedy's chelation theory [34]. According to Overtone's concept of cell permeability, the lipid membrane that surrounds the cell favors the passage of only lipid soluble materials due to which liposolubility is considered to be an important factor that controls the antimicrobial activity. Chelation reduces the polarity [35, 36 ] of the metal ion mainly because of the partial sharing of its positive charge with the donor groups and possibly the $\pi$-electron delocalization within the whole chelate ring system thus formed during coordination. This process of chelation thus increases the lipophilic nature of the central metal atom, which in turn favors its permeation through the lipoid layer of the membrane. This in turn is responsible for increasing the hydrophobic character and liposolubility of the molecule in crossing cell membrane of the microorganism and hence enhances the biological utilization ratio and activity of the testing drug/compound. The biological activity of compounds also depends on the nature of the ligand, concentration, lipophilicity, nature of metal ion, coordinating sites, and geometry of the complex.

3.3.2. Antifungal Activity. Based on the screening data from the antifungal studies, the following observations can be

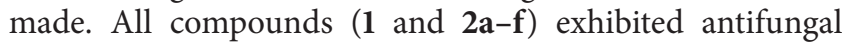
activity against different fungal strains (Figure 4). Schiff base 2,5-bis((4-bromophenyl) carbamoyl)terephthalic acid was found less active than its oligomer metal complexes. Compound $2 \mathbf{e}\left(\mathrm{ZOI}_{(\mathrm{PE})}=35 \mathrm{~mm}, \mathrm{ZOI}_{(\mathrm{BT})}=33 \mathrm{~mm}, \mathrm{ZOI}_{(\mathrm{NS})}=\right.$ $36 \mathrm{~mm}$, and $\mathrm{ZOI}_{(\mathrm{TS})}=34 \mathrm{~mm}$ ) was identified as more active against all fungal strains. Compound $\mathbf{2 b}\left(\mathrm{ZOI}_{(\mathrm{PE})}=33 \mathrm{~mm}\right.$, $\mathrm{ZOI}_{(\mathrm{BT})}=30 \mathrm{~mm}, \mathrm{ZOI}_{(\mathrm{NS})}=32 \mathrm{~mm}$, and $\mathrm{ZOI}_{(\mathrm{TS})}=31 \mathrm{~mm}$ ) also had good antifungal activity against fungal strains. Compounds 2a, 2c, 2d, and $\mathbf{2 f}$ exhibited moderate antifungal activity. Compounds $\mathbf{1}$ and $\mathbf{2 a}-\mathbf{f}$ exhibited less antifungal activity as compared to standard antibiotic drug, ketoconazole $\left(\mathrm{ZOI}_{(\mathrm{PE})}=43 \mathrm{~mm}, \mathrm{ZOI}_{(\mathrm{BT})}=42 \mathrm{~mm}, \mathrm{ZOI}_{(\mathrm{NS})}=45 \mathrm{~mm}\right.$, and $\left.\mathrm{ZOI}_{(\mathrm{TS})}=41 \mathrm{~mm}\right)$.

\section{Conclusions}

Ligand and its oligomer metal complexes have been synthesized and were duly characterized by various spectroscopic techniques. The geometry of a central metal ion was confirmed by electronic spectra and magnetic susceptibility measurements. Antimicrobial activity of ligand and its oligomer metal complexes suggests that the complexes are more potent than the ligand.

\section{Conflict of Interests}

The author declares that there is no conflict of interests regarding the publication of this paper.

\section{Acknowledgment}

The author is greatly thankful to the Principal, Government Science College, Gandhinagar, for providing the necessary research facility.

\section{References}

[1] A. C. Tsipis, "DFT flavor of coordination chemistry," Coordination Chemistry Reviews, vol. 272, pp. 1-29, 2014.

[2] D.-S. Li, J. Zhao, Y.-P. Wu et al., " $\mathrm{Co}_{5} / \mathrm{Co}_{8}$-cluster-based coordination polymers showing high-connected self-penetrating networks: syntheses, crystal structures, and magnetic properties," Inorganic Chemistry, vol. 52, no. 14, pp. 8091-8098, 2013.

[3] D.-S. Li, P. Zhang, J. Zhao et al., "Two unique entangling Cd IIcoordination frameworks constructed by square Cd 4-building blocks and auxiliary N,N'-donor ligands," Crystal Growth and Design, vol. 12, no. 4, pp. 1697-1702, 2012.

[4] Y. Hijikata, S. Horike, M. Sugimoto, M. Inukai, T. Fukushima, and S. Kitagawa, "Pore design of two-dimensional coordination polymers toward selective adsorption," Inorganic Chemistry, vol. 52, no. 7, pp. 3634-3642, 2013.

[5] B. Zheng, J. Luo, F. Wang et al., "Construction of six coordination polymers based on a 5,5'-(1,2-ethynyl)bis- 1,3benzenedicarboxylic ligand: Synthesis, structure, gas sorption, and magnetic properties," Crystal Growth \& Design, vol. 13, no. 3, pp. 1033-1044, 2013.

[6] Y.-Y. Liu, H.-Y. Liu, J.-F. Ma, Y. Yang, and J. Yang, "Syntheses, structures and photoluminescent properties of $\mathrm{Zn}(\mathrm{II})$ and $\mathrm{Cd}(\mathrm{II})$ coordination polymers with flexible tripodal triazolecontaining ligands," CrystEngComm, vol. 15, no. 10, pp. 18971907, 2013.

[7] M.-L. Tong, S. Hu, J. Wang, S. Kitagawa, and W. N. Seik, "Supramolecular isomerism in cadmium hydroxide phases. Temperature-dependent synthesis and structure of photoluminescent coordination polymers of $\alpha$ - and $\beta-\mathrm{Cd}_{2}(\mathrm{OH})_{2}(2,4-$ pyda)," Crystal Growth \& Design, vol. 5, no. 3, pp. 837-839, 2005. 
[8] W.-G. Lu, L. Jiang, and T.-B. Lu, "Lanthanide contraction and temperature-dependent structures of lanthanide coordination polymers with imidazole-4,5-dicarboxylate and oxalate," Crystal Growth and Design, vol. 10, no. 10, pp. 4310-4318, 2010.

[9] G.-P. Yang, Y.-Y. Wang, L.-F. Ma et al., "Hydrothermal syntheses and characterizations of three coordination polymers based on mixed organic ligands," European Journal of Inorganic Chemistry, vol. 24, pp. 3892-3898, 2007.

[10] J.-J. Wang, L. Gou, A.-M. Hu et al., "Ligand and pH-controlled ZnII bilayer coordination polymers based on biphenyl3,3',4,4'-tetracarboxylate," Crystal Growth and Design, vol. 7, no. 8, pp. 1514-1521, 2007.

[11] S. Q. Zang, Y. Su, Y. Li, Z. Ni, H. Zhu, and Q. Meng, "Interweaving of triple-helical and extended metal-O-metal singlehelical chains with the same helix axis in a $3 \mathrm{D}$ metal-organic framework," Inorganic Chemistry, vol. 45, no. 10, pp. 3855-3857, 2006.

[12] X. Duan, J. Lin, Y. Li, C. Zhu, and Q. Meng, "Syntheses, structures and properties of a series of organic-inorganic complexes based on methylenediisophthalic acid (H4MDIP)," CrystEngComm, vol. 10, no. 2, pp. 207-216, 2008.

[13] C.-Z. Mei, W.-W. Shan, and B.-T. Liu, "Synthesis, crystal structure and luminescent properties of one $3 \mathrm{D} \mathrm{Cd}(\mathrm{II})$ coordination polymer [Cd(H3BPTC)2(bpy)]n (H4BPTC = 1,1'-biphenyl$2,2^{\prime}, 6,6^{\prime}$-tetracarboxylic acid, bpy $=4,4^{\prime}$-bipyridine)," Spectrochimica Acta-Part A: Molecular and Biomolecular Spectroscopy, vol. 81, no. 1, pp. 764-768, 2011.

[14] C.-Z. Mei, J.-X. Wang, and W.-W. Shan, "Synthesis and crystal structure of an infinite sandwich-type $\mathrm{Cu}(\mathrm{I})$ coordination polymer: $[\mathrm{Cu}(\mathrm{abpy}) 2](\mathrm{H} 3 \mathrm{bptc}) \cdot(\mathrm{H} 2 \mathrm{O}) \mathrm{n}$ constructed by a tetracarboxylic acid," Chinese Journal of Structural Chemistry, vol. 30, no. 8, pp. 1194-1198, 2011.

[15] Y. S. Patel, H. S. Patel, and B. Srinivasulu, "Synthesis, spectral, magnetic, thermal and biological aspects of pyromellitic dianhydride based co-ordination polymers," International Journal of Plastics Technology, vol. 16, no. 2, pp. 117-124, 2012.

[16] Y. S. Patel, K. D. Patel, and H. S. Patel, "Spectral and antimicrobial studies on novel ligand and its co-ordination polymers," Journal of Saudi Chemical Society, 2012.

[17] Y. S. Patel, R. B. Dixit, and H. S. Patel, "Synthesis, characterization, and biological activity of coordination polymers derived from pyromellitic dianhydride," Turkish Journal of Chemistry, vol. 37, no. 6, pp. 978-986, 2013.

[18] Y. S. Patel, P. N. Patel, and H. S. Patel, "Studies on coordination polymers derived from 2,5-bis (naphthalen-1- ylcarbamoyl)terephthalicacid," Journal of Macromolecular Science A: Pure and Applied Chemistry, vol. 51, no. 2, pp. 134-143, 2014.

[19] S. F. Vanparia, T. S. Patel, N. A. Sojitra et al., "Synthesis, characterization and antimicrobial study of novel 4-[(8-hydroxyquinolin-5-yl)methyl]aminobenzenesulfonamide and its oxinates," Acta Chimica Slovenica, vol. 57, no. 3, pp. 660-667, 2010.

[20] A. I. Vogel, A Textbook of Quantitative Inorganic Analysis, Longman, London, UK, 3rd edition, 1961.

[21] G. H. Jeffery, J. Bassett, J. Mentham, and R. C. Denney, Vogels Textbook of Quantitative Inorganic Analysis, Longman, Harlow, UK, 5th edition, 1989.

[22] S. K. Chatterjee and N. D. Gupta, "Effects of structure and composition on the titration curves of some synthetic copolymers in non aqueous media," Journal of Polymer Science A: Polymer Chemistry, vol. 11, no. 6, pp. 1261-1270, 1973.

[23] R. Hasanzadeh, P. Najafi Moghadam, and N. Samadi, "Synthesis and application of modified poly (styrene-alt-maleic anhydride) networks as a nano chelating resin for uptake of heavy metal ions," Polymers for Advanced Technologies, vol. 24, no. 1, pp. 3441, 2013.

[24] S. Alam, "Synthesis, antibacterial and antifungal activity of some derivatives of 2-phenyl-chromen-4-one," Journal of Chemical Sciences, vol. 116, no. 6, pp. 325-331, 2004.

[25] M. J. Pelzar, E. C. S. Chan, and N. R. Krieg, Antibiotics and Other Chemotherapeutic Agents in Microbiology, Blackwell, New York, NY, USA, 5th edition, 1998.

[26] R. M. Silverstein and F. X. Webste, Webste, Spectrometric Identification of Organic Compounds, John Wiley \& Sons, New York, NY, USA, 6th edition, 2004.

[27] P. K. Panchal, P. B. Pansuriya, and M. N. Patel, "In-vitro biological evaluation of some ONS and NS donor Schiff's bases and their metal complexes," Journal of Enzyme Inhibition and Medicinal Chemistry, vol. 21, no. 4, pp. 453-458, 2006.

[28] K. Nakamoto, Infrared and Raman Spectra of Inorganic and Coordination Compounds, Wiley, New York, NY, USA, 3rd edition, 1978.

[29] A. B. P. Lever, Electronic Spectra of dn Inorganic Electronic Spectroscopy, Elsevier, Amsterdam, The Netherlands, 2nd edition, 1984.

[30] A. Malik, S. Parveen, T. Ahamad, S. M. Alshehri, P. K. Singh, and N. Nishat, "Coordination polymer: synthesis, spectral characterization and thermal behaviour of starch-urea based biodegradable polymer and its polymer metal complexes," Bioinorganic Chemistry and Applications, vol. 2010, Article ID 848130, 8 pages, 2010.

[31] E. M. Soliman and M. El-Shabasy, "Synthesis, characterization and electrical conductivity properties of homo- and heterodi and trimetallic complexes of mixed azo dyes," Journal of Materials Science, vol. 29, no. 17, pp. 4505-4509, 1994.

[32] J. Lewis and R. S. Wilkins, Modern Coordination Chemistry, Wiley-Interscience, New York, NY, USA, 1960.

[33] R. Pappalardo, "Note on the optical absorption of $\mathrm{MnCl}_{2}$ and $\mathrm{MnBr}_{2}$," The Journal of Chemical Physics, vol. 33, no. 2, pp. 613$614,1960$.

[34] B. G. Tweedy, "Plant extracts with metal ions as potential antimicrobial agents," Phytopathology, vol. 55, pp. 910-914, 1964.

[35] Z. H. Chohan, M. Arif, Z. Shafiq, M. Yaqub, and C. T. Supuran, "In vitro antibacterial, antifungal \& cytotoxic activity of some isonicotinoylhydrazide Schiff's bases and their cobalt (II), copper (II), nickel (II) and zinc (II) complexes," Journal of Enzyme Inhibition and Medicinal Chemistry, vol. 21, no. 1, pp. 95-103, 2006.

[36] Z. H. Chohan and C. T. Supuran, "Organometallic compounds with biologically active molecules: in vitro antibacterial and antifungal activity of some 1,1/-(dicarbohydrazono) ferrocenes and their cobalt(II), copper(II), nickel(II) and zinc(II) complexes," Applied Organometallic Chemistry, vol. 19, no. 12, pp. 1207-1214, 2005. 

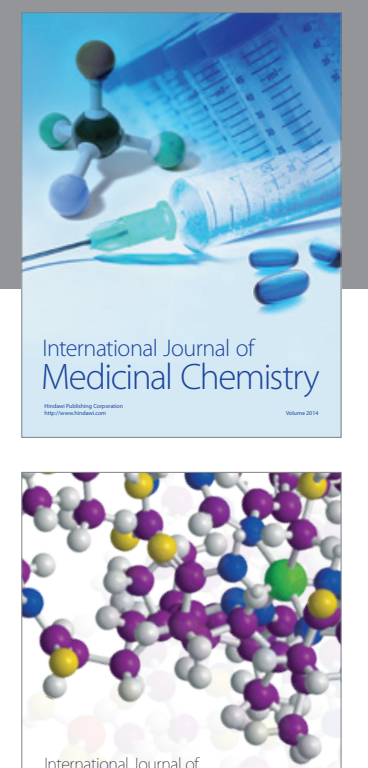

\section{Carbohydrate} Chemistry

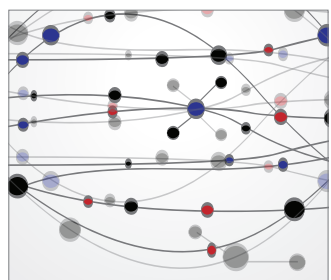

The Scientific World Journal
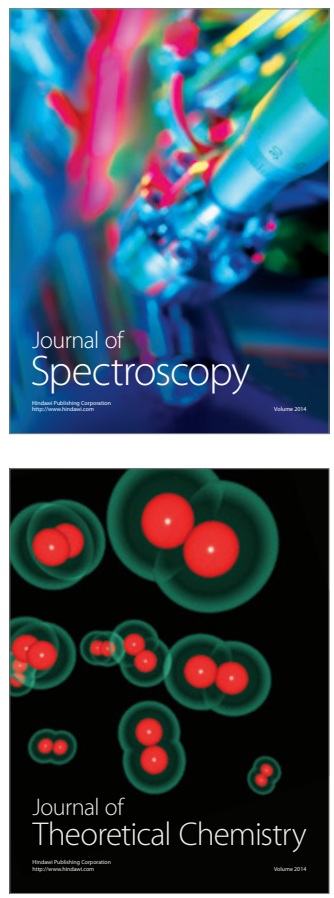
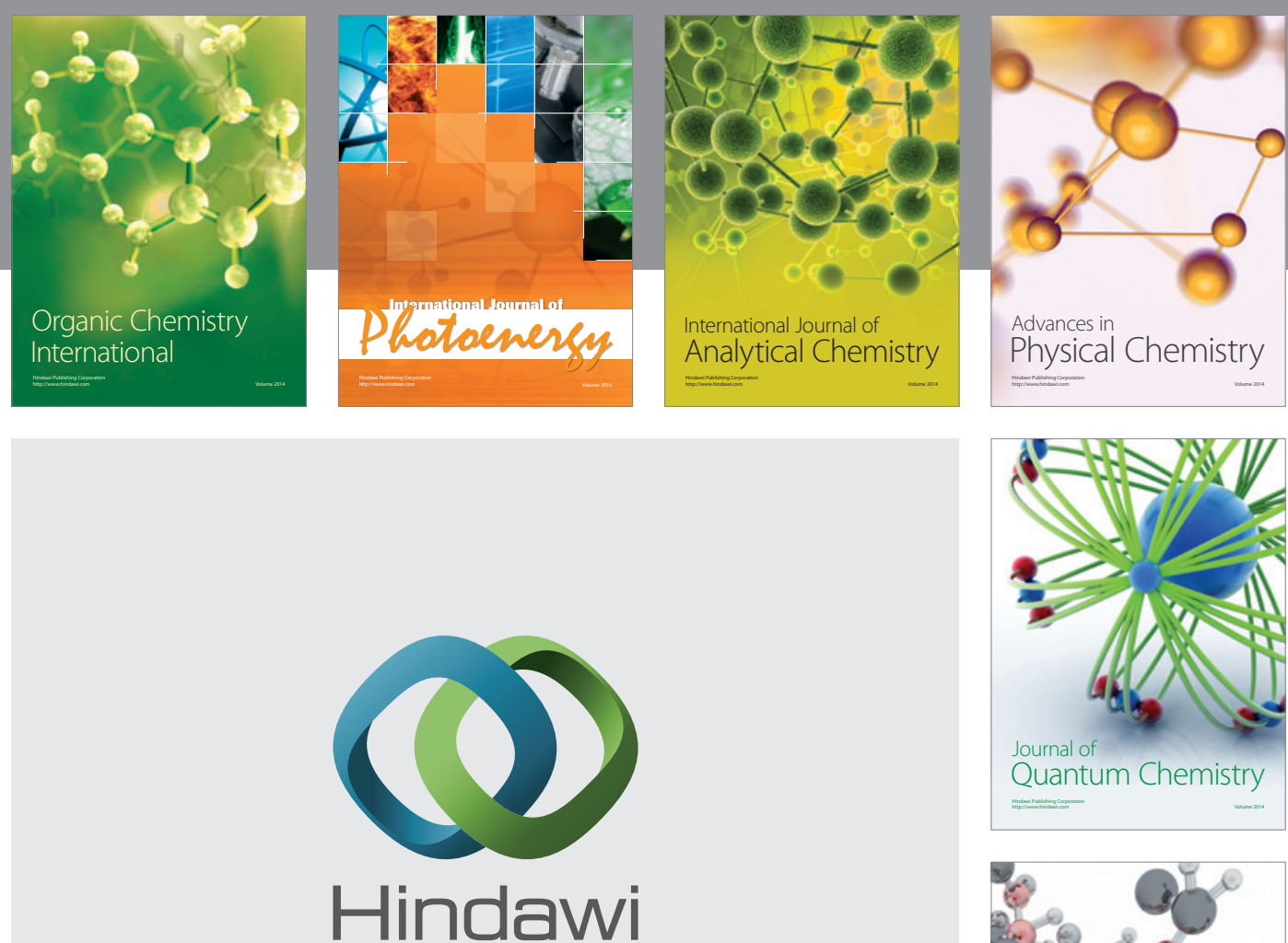

Submit your manuscripts at

http://www.hindawi.com

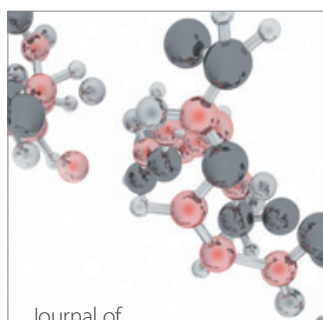

Analytical Methods

in Chemistry

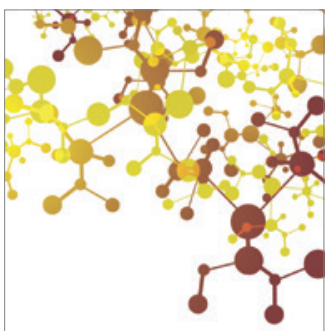

Journal of

Applied Chemistry

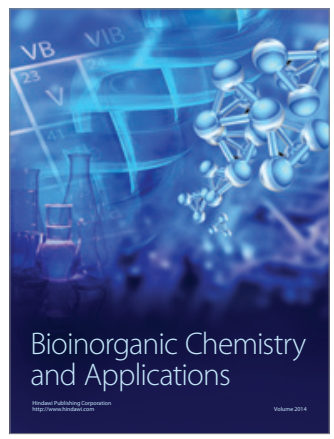

Inorganic Chemistry
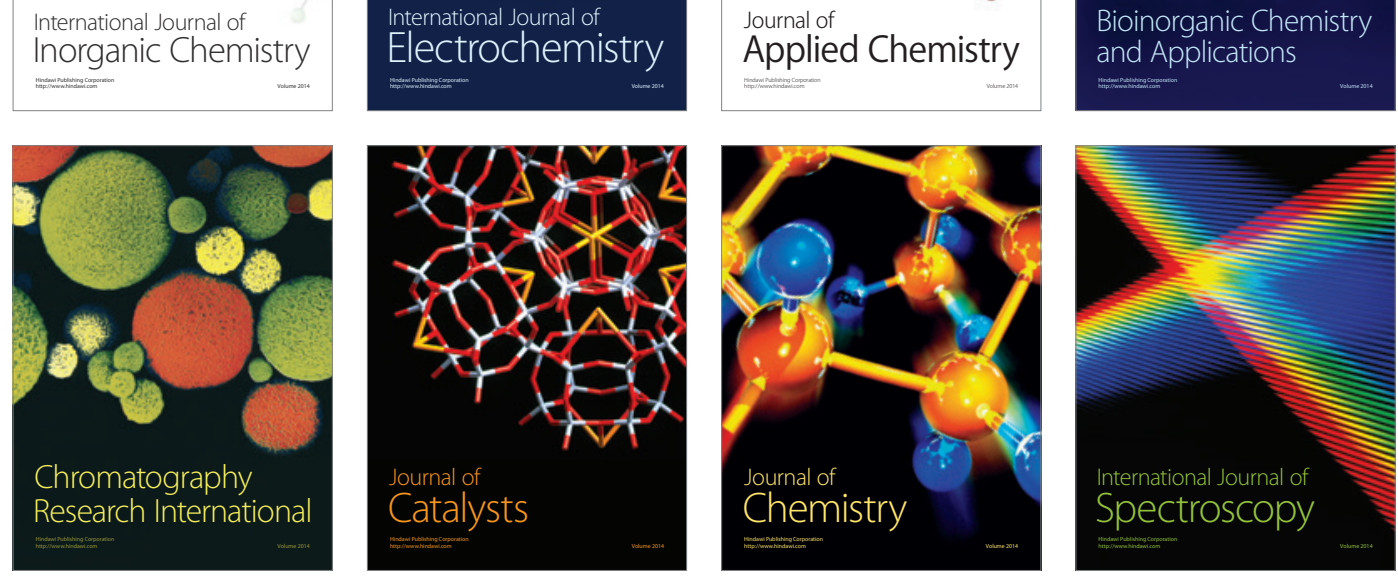